\title{
APLIKASI TEORI FONOLOGI PADA PENANGANAN ANAK BERKESULITAN MEMBACA
}

\author{
Rifa Hidayah \\ Fakultas Psikologi \\ Universitas Islam Negeri (UIN) Maulana Malik Ibrahim Malang \\ Jl. Gajayana 50 Malang Telp. 0341-558916
}

\begin{abstract}
Abstrak - Kesulitan membaca atau sering di sebut disleksia merupakan salah satu kesulitan belajar khusus dalam membaca. Membaca merupakan kemampuan dasar yang wajib dimiliki anak dalam menempuh pendidikan. Mengingat pentingnya kemampuan membaca bagi semua orang maka pemahaman kesulitan membaca dan intervensinya melalui berbagai macam pendekatan sangat penting. Tulisan berikut ini akan mendiskusikan pentingnya penanganan kesulitan membaca pada anak berdasarkan pendekatan teori fonologi. Penanganan anak berkesulitan membaca membutuhkan pelayanan yang kompleks, demikian pula pelatihan kesadaran fonologi sebagai salah satu model pengembangan teori defisit fonologi akan lebih efektif bila dikombinasikan dengan pelatihan yang lain, antara lain fonologi dengan ketrampilan bunyi bahasa, ketrampilan huruf dan visual taktil-auditori sensori motorik.
\end{abstract}

Kata Kunci: Kesulitan membaca, anak, teori fonologi

PSIKOISLAMIKA. Jurnal Psikologi Islam (JPI) copyright @ 2013 Laboratorium Penelitian, Kajian Psikologi Islam dan Penerbitan. Volume 10. Nomor 2, Tahun 2013

\section{PENDAHULUAN}

Kemampuan membaca merupakan kemampuan dasar pada jenjang pendidikan dasar dan SD merupakan satuan pendidikan yang memberikan kemampuan dasar tersebut sebagaimana yang dinyatakan dalam Bab II pasal 3 PP No. 28/1990 tentang Pendidikan Dasar. Initinya aktivitas membaca buku sangat penting bagi anak untuk kehidupan mendatang, aktivitas belajar pada anak di mulai dari bagaimana individu membaca, karena itu bagi anak yang sulit membaca maka akan ketinggalan banyak informasi, oleh karena itu maka anak yang berkesulitan membaca memerlukan berbagai bantuan, yang mendukung kesuksesan belajar anak nantinya. Memahami anak disleksia dan teori mana yang tepat untuk dilakukan intervensi bagi anak disleksia sangat penting. Disleksia merupakan kondisi dimana seorang mengalami kesulitan membaca gangguan yang paling sering terjadi pada masalah belajar, dan 5-10\% orang terkena disleksia (Wolfensberger \& Ruijssnaars, 1997). Berdasarkan penelitian (Hidayah, 2009) kemampuan membaca dan menulis anak disleksia tergolong rendah.

Salah satu cara nya dilakukan dengan keterampilan khusus dalam pemberian instruksi atas anak mengalami kesulitan membaca, yaitu: (1) memberikan kesempatan untuk mencoba mempraktekan dengan panduan terhadap keterampilan baru, (2). pemberian instruksi yang cukup intensif Isyarat yang sistematik dengan strategi yang tepat dalam membaca kata ataupun teks/paragraf, (3). instruksi yang cukup tegas dalam strategi pengkodean fonemik (Wolf, 2000). Tulisan ini akan membahas kesulitan belajar ditinjau dari pendekatan teoritik defisit fonologi secara kritis, dengan harapan mampu memberikan intervensi yang lebih efektif bagi anak disleksia.

\section{KERANGKA KERJA TEORITIK Kesulitan Membaca (Disleksia)}

Disleksia merupakan gangguan dalam proses membaca, mengucapkan (melafalkan), menulis dan terkadang sulit untuk memberikan kode (pengkodean) angka ataupun bahasa yang memberikan 
efek terhadap proses belajar (Sowling, 2000) dan gangguan membaca (sebab proximal) sebagai akibat dari kelemahan fonologi (sebab distal), cirinya adalah lemah dalam membaca (non kata), dan penampilan yang busruk dalam tugas-tugas fonologi (Erskine, 2005).

Anak disleksia memiliki beberapa karakater, antara lain memiliki kemampuan/ketidakakuratan yang lemah dalam pengenalan kata (Miller, 2004), (a). terlambat bicara dan memiliki masalah pada awal belajar berbicara, (b). kesulitan dalam memberikan nama (pengidentifikasian) suatu objek dan kesulitan peniruan kata, (c). memiliki kemampuan ingatan jangkan pendek yang rendah (d). kesulitan dalam memberi tanda (memberi garis) suatu lingkaran, (e). kurang mampu dalam mengulang kata yang diucapkan/ meniru kata-kata (Wadlington, 2000).

\section{Kesulitan Membaca Ditinjau Dari Pendekatan Teori Deficit Fonologi (Phonological Deficit Theory)}

Pendekatan teori deficit fonologi memandang bahwa orang yang mengalami disleksia mempunyai kelemahan fonologi yang menyebabkan kesulitan dalam menggambarkan fonem (Coleman, 1990 dalam Ramus, 2004). Teori ini lebih menyoroti bahwa seorang yang sulit membaca akibat kelemahan fonologi, sebagai faktor tunggal. Berbagai peneltian yang telah mendukung pendapat toeri ini banyak di dukung oleh pakar neuropsycological dalam berbagai penelitiannya menunjukkan bahwa kesulitan belajar anak bersumber dari fonologi, selain itu problem baca tulis berasal dari kelemahan kognitif, yang secara khusus berkaitan dengan proses berbicara (Snowling, 2000), penelitian Thorneus di tahun 1984 (dalam Snowling, 2000) juga meunjukkan bahwa anak-anak disleksia sebagai sutau kelompok yang menunjukkan inferior dalam kemampuan fonologi.

Kelemahan fonologi mempunyai beberapa konsekuensi, yang tidak semuanya berkaitan secara langsung dengan problem baca tulis. Sebagai gejala kunci dari konsekuensi yang ditimbulkan akibat kelemahan fonologi adalah (1). keterbatasan dalam memori verbal jangka pendek/poor verbal shortterm memory (2). kesulitan menamai/slow lexical retrieval serta (3). kesadaran fonologi yang lemah/ poor phonological awareness serta kemampuan mengulang rendah (Fowler, 1991, dalam Snowling, 2000). Lebih lanjut Pennington (1991) berpendapat bahwa disleksia adalah kelemahan dalam fonologi, dan kelainan genetis serta pengaruh neurologi (syaraf) menyebabkan gangguan dalam wilayah kognitif. Secara terperinci teori dapat lihat dalam bagan berikut:

Teori Defisit Fonologi (Adaptasi Ramus, 2004: Hal. 3)

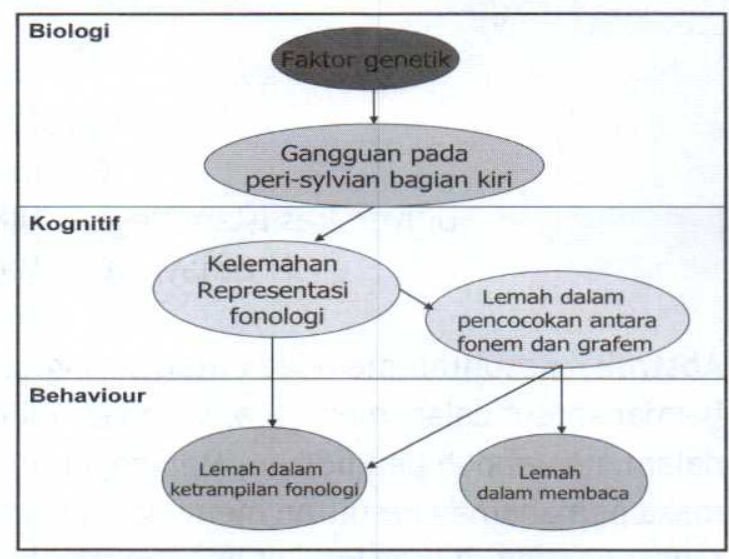

Gambar 1

Teori deficit fonologi, diadaptasi dari Ramus 2004, hlm 3 (dalam Hidayah, 2009)

Berdasarkan Gambar 1, bahwa berdasarkan teori deficit fonologi bahwa bahwa gangguan pada kelemahan proses fonologi yang berakibat pada lemahnya kemampuan membaca dipengaruhi oleh kelainan genetis dan kelainan saraf (peri hemisper kiri). Representasi fonologi bermakna penggunaan informasi fonologi (yaitu bunyi dari suatu bahasa) dalam pemrosesan bahasa tertulis maupun lisan. Ketrampilan fonologi sendiri merupakan memproses tulisan dan bahasa lesan dengan menggunakan informasi fonologi (Wagner dan torgesen, 1987 dalam Wing, 2005).

Ketrampilan pemrosesan fonologis ini terdiri dari tiga macam ketrampilan yaitu; kesadaran fonologis/phonological awareness (e.g. Mann \& Liberman, 1984; Liberman \& Shankweiler, 1985), retrieval of phonological codes from long-term memory (rapid automatized naming) (e.g. Bowers \& Swanson, 1991), dan ingatan verbal jangka pendek/ verbal short-term memory (e.g. Catts, 1989; Mann \& Liberman, 1984; Wagner dan Torgessen, 1987 dalam Boets, 2007).

Pembahasan fonologi akan diuraikan dalam kajian berikut:

a). Kesadaran fonologi/phonological awareness. Berbagai hasil penelitian menunjukkan bahwa kesadaran fonologi merupakan prediktor terbaik pada kesuksesan membaca permulaan (Chan, 2001). Kesadaran fonologi menurut Stanovich (Wing, 2005) adalah sensitivitas anak atau 
kesadaran eksplisit akan struktur bunyi dari kata-kata yang diucapkan dalam bahasanya. Kesadaran fonologi difahami oleh anak secara baik sebagaimana pendapat Runge (2002), terdapat dalam 2 dimensi yaitu (i). tugas kategorisasi suara, blending (campuran), pembagian, dan manipulasi/ phoneme awareness task, serta (2). tugas rhyming (sajak). Anak dikatakan mencapai kesadaran fonologis ketika anak menyadari bahwa kata-kata yang diucapkannya terdiri dari rangkaian bunyi-bunyi tunggal (fonem) dilambangkan dalam bentuk karakteristik alfabetik (grafem). Karena itu apabila anak tidak mampu membaca sebuah kata baru dengan menggunakan pengetahuan tentang asosiasi grafem-fonem tersebut menandakan bahwa anak telah mencapai kesadaran fonologis yang rendah yang berakibat anak mengalami disleksia (Meyler, 2005). Kesadaran fonologis ini telah diteliti secara berulang dalam berbagai studi korelasional, longitudinal dan eksperimental dalam kaitannya dengan keberhasilan membaca permulaan antara lain: (1). Burgess and Lonigan (1998) penelitian longitudinal selama 1 tahun terhadap 97 anak yang berusia 4 sampai 5 tahun menunjukkan bahwa kesadaran fonologi sebagai prediktor dalam pengetahuan huruf dan pengetahuan huruf memiliki konstribusi terbesar dalam kesadaran fonologi, (2). korelasi antara kesadaran fonologi dan kemahiran membaca (Murray, 1998), (3). Marshall (2001) dalam penelitiannya menunjukkan bahwa anak-anak disleksia mengalami kelemahan pada ketrampilan fonologi, (4). Suk (2005) menunjukkan bahwa secara umum anak disleksia mereka lemah dalam proses fonologi, baik dalam bahasa china maupun bahasa inggris.

b). Rapid automatized naming. Makna dasarnya kecepatan menamai. Rapid automatized Naming merupakan proses yang mendasari kecepatan mengenali stimuli bahasa yang ditampilkan secara visual. Dalam penelitian neuro science, ada bukti yang kuat bahwa banyak pembaca disleksia lemah dalam kecepatan menamai, yaitu kelemahan dalam proses yang mendasari kecepatan mengenali stimuli bahasa yang ditampilkan secara visual (Ackerman \& Dykman, 1993 et al.). Lebih lanjut disampaikan dalam suatu penelitian menunjukkan bahwa kelemahan fonologi sangat signifikan dengan kecepatan menamani (speed naming) pengukuran huruf, jumlah kecepatan menamai. Yaitu orang disleksia mempunyai kesulitan dalam menyimpan kata-kata dalam memori jangka pendek, dan memisahkannya kedalam fonem (Ramus, 2001).

c). Verbal short term memory. Memori verbal jangka pendek merupakan memori jangka pendek yang diperlukan bagi kemampuan membaca. Pembaca disleksia mempunyai rentang memori yang normal untuk informasi visual, tapi kemampuan mengingat dalam rentang jangka pendek secara verbal lebih rendah bila dibandingkan dengan pembaca normal yang secara umur kronologis sama artinya bahwa pembaca disleksia kurang efisien daripada pembaca normal ketika disyaratkan untuk mendapatkan kode memori fonetik (Hulme, et al. 1981, dalam Carrol, 2003). Pembaca disleksia juga mempunyai kesulitan menyimpan kata-kata dalam memori jangka pendek, dan memisahkannya ke dalam fonem (Ramus, 2001), dan untuk melihat apakah anak disleksia memiliki kelemahan dalam memori verbal jangka pendek dapat diketahui melalui tes rentang angka atau mengulangi huruf. Diperoleh dengan menggunakan tes digit span dari WISC-revised (Weschker, 1974) yang terdiri atas dua aspek yaitu: mengulang kata (repeated forwards) dan kembali pada kata (back wards).

\section{DISKUSI DAN PEMBAHASAN}

Model pelatihan fonem sudah banyak diterapkan di Indonesia dan membawa hasil yang menyenangkan sebagaiamana hasil penelitian: Widyastuti (1999), Fitriyati (2004), Ayriza, (1995), Hadi (1997), Widyana, R. (1999) bahwa pelatihan kesadaran fonemik penting untuk meningkatkan kemampuan pra-membaca Anak-anak Prasekolah, yang berarti bahwa pengajaran membaca awal melalui pelatihan fonologi penting untuk meningkatkan sumberdaya manusia termasuk mengurangi jumlah anak yang sulit membaca.

Teori deficit fonologi ada memiliki berbagai kelebihan untuk dapat di terapkan dalam sebuah intervensi penangan anak berkesulitan membaca. Kelebihan-kelebihan tersebut antara lain; a). Teori ini mampu menjelaskan secara detil tentang disleksia sebagai akibat kelemahan fonologi. Teori ini didukung oleh banyak penelitian di antaranya: (1). Hasil penelitian menunjukkan bahwa ketidakmampuan membaca disebabkan oleh kelemahan fonologi dan fonologi merupakan 
salah satu prediktor penting dalam menumbuhkan serta mengembangkan kemampuan awal membaca pada anak-anak (Sparks, 2004; Sofie, et.al, 2002; Jimenez, 2003; Scheneider dkk, 2000; Wolfgang, 2000; Kleeck, 1998; dan Murray, 1998, dan Torgesen et al, 1992). (2). Banyak studi yang menunjukkan bahwa keterampilan fonologi bisa memprediksi penguasaan membaca, tidak hanya dalam bahasa inggris tetapi juga bahasa china (Ho and Bryant, 1997; Chan, 2003, Suk, 2005, Yin, 2003).

b). Meskipun teori fonologi menimbulkan banyak kritik sehingga muncul teori temporal auditori, yang menyatakan bahwa penyebab disleksia adalah karena gangguan pendengaran akan tetapi teori fonologi ternyata masih bertahan dan mampu menjelaskan tentang masalah ketidakmampuan membaca karena kelemahan fonologi semata. Sebagaimana hasil meta analisis menunjukkan bahwa hanya $40 \%$ dari orang disleksia yang mengalami kelemahan proses auditori (Ramus, 2001) ini berarti 60\% faktor lain lebih tinggi, karena itu berarti bahwa disleksia bukan satu-satunya kelemahan auditori (Habib, 2000). Hasil penelitian Goswami (2002) membuktikan bahwa anak-anak yang mengalami disleksia kebanyakan mengalami kekurangan dalam repesentasi fonologi. Gottardo (2001) melakukan penelitian pada 65 anak-anak cina yang mempelajari bahasa Inggris sebagai bahasa kedua, hasilnya menunjukkan adanya korelasi antara kemampuan membaca dan proses fonologi. Hasil penelitian Lianeu (1999) pada 122 anak perancis adalah adanya relasi antara kesadaran fonologi dalam bahasa perancis terhadap prestasi membaca begitu pula pada bahasa inggris sebagai bahasa kedua. Penelitian Meyler (2005) yang membandingkan antara 17 disleksia dan 16 anak normal menunjukkan bahwa anak disleksia lemah dalam fonologi. Penelitian lain juga menunjukkan bahwa anak-anak disleksia mengalami kelemahan pada ketrampilan fonologi.

c). Pembelajaran sajak yang merupakan salah satu model pembelajaran fonologi banyak berhasil diterapkan dan efektif meningkatkan kemampuan baca pada anak disleksia. Beberapa hasil penelitian telah menunjukkan di antaranya; penelitian Carrol (2003) terhadap 67 anak prasekolah menunjukkan bahwa ketrampilan artikulasi dan suku kata serta kesadaran sajak merupakan prediktor dari kesadaran disleksi. d). Teori ini juga menjelaskan ingatan jangka pendek sebagai kelemahan yang dimiliki anak disleksia. Pendapat ini didukung hasil penelitian lintas budaya Byrne (2002) terhadap 146 anak prasekolah di australia, 248 di Amerika, 70 anak di Norgewia, berdasarkan pengukuran kognitif menunjukkan bahwa pengaruh genetik pada kesadaran fonologi dan beberapa pengukuran pada memori dan belajar. Berdasarkan pendapat National Reading Panel, (2000) yang menyatakan bahwa intervensi disleksia lebih berhasil dengan menggunakan cara pengulangan membaca terutama karena lemahnya ingatan jangka pendek bagi disleksia. Penelitian Bell (2003) terhadap 105 partisipan (random) dari SD dan SMP mengikuti tes membaca dan kemampuan kognitif. Faktor analisis dari variabel-variabel kognitif ini (termasuk proses auditory, kesadaran fonologi, memory auditory jangka pendek, memory visual, menamai secara cepat dan kecepatan proses visual) menghasilkan 3 faktor empiris dan teoritis (proses auditori, proses visual dan memori) yang masing-masing memberi kontribusi untuk prediksi kemampuan membaca dan mengeja.

Pengembangan model kombinansi pelatihan fonologinya akan efektif dilakukan di Indonesia, melalui pendidikan inklusi yang ditawarkan pemerintah melalui Direktorat Pendidikan Luar Biasa, Direktorat Jenderal Pendidikan Dasar dan Menengah, sesuai amanat UUSPN No. 2/1989 agar setiap warga negara memiliki hak yang sama untuk memperoleh pendidikan. Karena itulah pelaksanaan pendidikan inklusi bagi anak berkesulitan belajar secara terencana dan terprogram sebaik mungkin akan dapat membantu meningkatkan kualitas kemampuan membaca anak. Selain itu perlu pula dikembangan metode belajar yang menyenangkan dan kesempatan belajar bagi anak disleksi seluas-luasnya dan disesuaikan dengan kondisi anak disleksia, seperti pelatihan kesadaran fonologi yang dikombinasikan dengan pelatihan multisensoris misalnya melalui VAKT (visual, auditory, kinesthetic, and tactile), maupun metode analisis glass. Penerapan kesadaran pelatihan fonologi bagi disleksia, diperlukan pula bimbingan orangtua misalkan melalui bimbingan untuk fasih berbahasa dengan cara mengulang kata atau membaca secara lesan, dan dapat dilakukan dengan alat bantu, seperti papan, laptop, musik atau komputer (Vance, 2004).

\section{KESIMPULAN}

Teori deficit fonologi masih relevan dan penting digunakan untuk menjelaskan permasalahan disleksia dan intervensisnya, sebagaimana banyak penelitian telah membuktikannya bahwa kelemahan fonologi sebagai penyebab disleksia (Sparks, 2004; Sofie, et.al, 2002; Jimenez,2003; Scheneider dkk, 2000). Pelatihan fonologi relevan untuk diterapkan bagi 
anak disleksia akan tetapi untuk lebih mencapai hasil yang lebih baik bagi disleksia penulis lebih sepakat bahwa pelatihan fonologi perlu dikombinasikan dengan pelatihan/intervensi lain sehingga terwujud hasil yang lebih baik. Artinya bahwa akan lebih efektif jika dalam intervensi disleksia tidak hanya menggunakan ketrampilan fonologi sebagai alat tunggal untuk meningkatkan kemampuan membaca, karena itu perlu dikombinasikan seperti kombinasi antara fonologi dengan ketrampilan bunyi bahasa, ketrampilan huruf, dan visual taktil- auditori sensori motorik menjadi suatu alat kombinasi yang cukup memadai digunakan dalam penanganan masalah disleksia, karena penanganan kasus disleksia membutuhkan pelayanan yang kompleks.

Pendapat ini didukung oleh beberapa hasil penelitian, contohnya penelitian Lovett (2000) bahwa pendekatan remedial (kombinasi fonologi; analisis fonologi/instruksi langsung dan pelatihan

\section{DAFTAR PUSTAKA}

Beacham, Nigel A. and James L. Alty (2006). An investigation into the effects that digital media can have on the learning outcomes of individuals who have dyslexia. Computers and Education. 47 74-93

Bell, Sherry Mee.Toward. (2003). a researchbased assessment of dyslexia. The Impact of Environmental Factors on Components of Reading and Dyslexia. Journal of Learning Disabilities; 36, 1; ProQuest Medical Library.pg. 505

Byrne Brian; Cara Delaland; Ruth Fielding-Barnsley; Peter Quain; et al (2002). Longitudinal twin study of early reading development in three countries: Preliminary result. Annals of Dyslexia; 52, ProQuest Medical Library. pg. 49

Badian N.A. (2006) do preschool ortografic skills contribute to prediction of reading.predection and prevention of reading failure, Journal of educational Psychology. pp 31-56

Bus, G. Andriana, and Ijzendoorn, Van.1999. Phonological Awareness and early Reading: A.Meta-Analysis of Experimental Training Studies. Journal of educational Psychology. Vol. 91.3. 403-414

Carrol. M, Julia.2003. the development of phonological awareness in pre school children. Developmental psychology. Vol 39.no 5. 913-923.

Chan, C,K.K. (2001), Phonological Processing In Reading Chinese Among Normaly Achieving strategi identifikasi) efektif untuk meningkatkan kemampuan membaca bagi anak kesulitan belajar. Wolfoang (2002) menyarankan pentingnya training kombinasi ketarampilan fonologi, pemahaman huruf, pelatihan huruf-suara menunjukkan efek yangang paling kuat pada keterampilan membaca dan mengeja di kelas 1 dan 2. Program yang efektif untuk siswa yang terkena disleksia menurut Wadlington (2000) adalah dengan menggunakan instruksi multi sensor, dan lingkungan belajar yang konsisten, teratur, yang memotivasi sebagaimana membangun harga diri. Selain itu Kesadaran fonem (kata-kata bisa dipilah-pilah dalam segmen suara) dianggap penting untuk kesuksesan dalam membaca. Hasil penelitian eksperimen Erlbo (2005) terhadap 35 anak menunjukkan adanya efek dari kesadaran fonologi dan pelatihan bunyi kata dapat meningkatkan kemampuan baca bagi anak disleksia.

And Poor Reader. Journal Of Experimental Child Psychology, 80,23-43

Chan, David W Connie Suk-Han Ho; Suk-Man Tsang; Suk-Han Lee; Kevin K H Chung. (2003). ReadingRelated Behavioral Characteristics of Chinese Children with Dyslexia. Annals of Dyslexia; 53, ProQuest Medical Library pg. 300

Carolyn, A Denton; Jack M Fletcher; Jason L Anthony; David J Francis. (2006). An Evaluation of Intensive Intervention for Students with Persistent Reading difficulties Journal of Learning Disabilities; 39, 5; ProQuest Medical Library. pg. 447

Deacon, S Hélène; Rauno Parrila (2006) John R Kirby Processing of Derived Forms in HighFunctioning Dyslexics. Annals of Dyslexia; Jun; 56, 1; ProQuest Medical Library. pg. 103

Elbo Carsten, Dorthe Klint oeterson, (2004). Long-term effect of phoneme awareness and letter sound training: an interventions study with children at risk for dyslexia. Journal of educational Psychology .Vol. 96.No. pp. 4.660-670

Erskine M, Jane (2005). Proximal Analysisi of Developmenl Dyslexia in Adulthood: The Cognitif Mosaic Model. Journal of educational Psychology. Vol. 97. No.3,406-424

Fisher, Simon E. and John C.DeFriesł. (2002) Developmental Dyslexia: Genetic Dissection Of A Complex Cognitive Trait.. vol 3. Nature Publishing Group.767-780.

Fitriyanti.2004. Kemampuan Membaca Permulaan 
Siswa Kelas I SD Ditinjau Dari Kesadaran Fonologis

Dan Inteligensi. Tesis. Yogyakarta: UGM

Goswami, Usha, Annals of Dyslexia; (2002); Phonology, reading development, and dyslexia: A crosslinguistic perspective. 52, ProQuest Medical Library. pg. 141

Gottardo, A. Yan, B.Siegel,L.S and Wade-woollley, L.(2001).factors related to English reading performance in children with Chinese as first language:more evidence of cross language transfer of phonological processing. Journal of educational Psychology. Vol. 93. No.530542.

Habib, Michel. 2000. the neurological basic of developmental dyslexia an overview and working hypothesis. Brain. 123.2373-2399.

Hidayah, (2009), Kemampuan baca-tulis siswa disleksia. Jurnal lingua, 4 (1)

Jimenez; Juan E Maria del Rosario Oritz; Mercedes Rodrigo; Isabel Hernandez-V. (2003). Do the effects of computer-assisted practice differ for children with reading disability. Journal of Learning Disabilities;36, 1; ProQuest Medical Library. pg. 34

Jawa pos, 4 januari 2006

KleeckAnne van; ROnald B Gillam; Teresa U McFadden (1998). A study of classroom-based phonological awareness training for preschoolers. American Journal of Speech - Language Pathology; 7, 3; ProQuest Medical Library. pg. 65

Lovett. Maureen W. (2000). Components of effective remediation for developmental reading disability: combining phonological and strategy-based instruction to improve outcomes. Journal of educational Psychology.

Michael, Ryan, (1992). The Social and Emotional Effects of Dyslexia The Education Digest; Jan; 57, 5; Academic Research Library. pg. 68

Meyler. Ann; Zvia Breznitz. (2005). Impaired Phonological and Orthographic Word Representations Among Adult Dyslexia. The Journal of Genetic Psychology; 166, 2; ProQuest Medical Library pg. 215.

Marshall, Catherine M; Margaret J Snowling; Peter J Bailey. (2001). Rapid auditory processing and phonological ability in normal readers and reading. Journal of Speech, Language, and Hearing Research; 44, 4; ProQuest Medical Library. pg. 925.

Miller-Shaul, Shelley,; Zvia Breznitz. (2004). Electrocortical Measures During a Lexical Decision Task: A Comparison Between .... The
Journal of Genetic Psychology; Dec; 165, 4; ProQuest Medical Library. pg. 399

Nicolson, R.I., Fawcett, A.J., and Dean, P. (2001). Developmental dyslexia: The cerebellar deficit hypothesis. Trends in Neurosciences. 24, 506-514.

Nicolson, R.I., Fawcett, A.J. and Dean, P. (1995). Time estimation deficits in developmental dyslexia: Evidence for cerebellar involvement. Proceedings of the Royal Society: Biological Sciences, 259, 43-47.

Nicolson, R.I., Fawcett, A.J., Berry, E.L., Jenkins, H., Dean, P. and Brooks, D.J. (1999). Association of abnormal cerebellar activation with motor learning difficulties in dyslexic adults. The Lancet, 353, 1162-7.

Pusat Penelitian Kebijakan, (1999), Penelitian tentang Pendidikan Luar Biasa, Jakarta: Puslit

Ransby, Marilyn J; H Lee Swanson. (2003). Reading Comprehension Skills Of Young Adults With Childhood Diagnoses Of Dyslexia. Journal Of Learning Disabilities; Nov/Dec; 36, 6; Roquest Medical Library. Pg. 538.

Richman Lynn C; Tammy Wilgenbusch; Thomasin Hall. (2005) The Cleft Palate - Craniofacial Journal; 42, 5; ProQuest Medical Library. pg. 565

Ramus. Franck 2004. Neurobiology of dyslexia : A reinterpretation of the data. Trends in Neurosciences 27 (12) p: 1-9

Runge, Timothy R. (2006). The structur of phonological Awareness Among Kondergaten student. Journal of educational Psychology. Vol.35. No. 3.pp370-386.

Snowling, M. J. (2000). Dyslexia. Blackwell: Oxford.

Stein, John and Walsh, Vincent . (1997). To see but not to read; the magnocellular theory of dyslexia.E. Marban and G.F. Tomaselli - Ion channels as enzymes. Trends in Neuroscience, 20, 147-152.

Singer, Elly. (2005) The Strategies Adopted by Dutch Children with Dyslexia to Maintain Their Self. Journal of Learning Disabilities; Sep/Oct 38, 5; ProQuest Medical Library pg. 411

Schiff, Rachel; Dorit Ravid (2004), Representing Written Vowels in University Students with Dyslexia Compared. Annals of Dyslexia; 54, 1; ProQuest Medical Library. pg. 39

Suk, Connie et al. (2005). Do Chinese dyslexia children have difficulties learning English as second language. Journal of psycholinguistic research.vol. 34.no.6. 
Sofie Cecilia A; Cynthia A Riccio. (2002). A comparison of multiple methods for the identification of children with reading. Journal of Learning Disabilities; 35, 3; ProQuest Medical Library. pg. 234

Smith, Allan B.Jenny Robert, Susan Lambrecht Smith, (2006). Reduced speaking rate as an early predictor of reading disability. Journal of Speech, Language, and Hearing Research;15:3.; ProQuest Medical Library. pg. 289.

Serniclaes Willy; Liliane Sprenger-Charolles; Rene Carre; Jean-Francois Demonet (2001). Perceptual discrimination of speech sounds in developmental dyslexia. Journal of Speech, Language, and Hearing Research; Apr; 44, 2; ProQuest Medical Library/ pg. 384.

Torgessen, JK. Morgan, ST, Davis, C. 1992. Effect of Two Types of Phonological Awareness Training on Word Learning in Kindergarten Children. Journal of Educational Psychology. 84. 364-370.

Theresa, A.Robert. (2005) Effect of alfabert letter instructions on yaoung children's word recognition. Journal of educational Psychology. Vol 95.no.1, 41-51.

Vance, Kate O'Brien (2004). Adapting Music Instruction for Students with Dyslexia. Music Educators Journal; May; 90, 5; Academic Research Library. pg. 27
Wadlington, Elizabeth . (2000). Effective language arts instruction for students with dyslexia. Preventing School Failure; 44, 2; Academic Research Library. pg. 61.

Wing, Bonnie (2005). Phonological processing skills and early reading abilities in Hongkong Chinese kindergarteners learning to read English as a. second language. Journal of educational Psychology. Vol. 97. No.1,81-87.

Widyana, R. 1999. Efektivitas Pelatihan Kesadaran Fonemik dalam Meningkatkan Kemampuan Pra-Membaca Anak-anak Prasekolah.Tesis. Yogyakarta. Program Pascasarjana UGM.

Widyastono, 1998. Siswa SD yang berkesulitan Belajar Umum dan Penanganan Kesulitan Belajar Membaca. Kajian Dikbud no. 013 tahun IV Juni 1998., hal 20-27.

Wolfgang Schneider. (2000). Traning phonological skills. Dyslexia in Chinese: Clues from Cognitive Neuropsychology. Vol.92.no2.284-295.

Weggelaar, Cornelis (2006). Kinesthetic Feedback And Dyslexic Students Learning To Read And Write. Et Cetera;; 63, 2; Academic Research Library. Pg. 144

Wolf, Maryanne. (1999). The Doble Hipotesis For Develompmental Dyslexia.Journal of educational Psychology. Vol.91.No 3.415-438.

Yin, Wen Gang; (2003) Brendan Stuart Weekes. Annals of Dyslexia; 53, ProQuest Medical Library pg. 255 